\title{
National Institutes of Health seek to speed up therapeutic innovations
}

$\mathrm{T}$ hese are exciting times in medical research, no doubt. Too often, that excitement peters out long before the fruits of the laboratory ever become a treatment or a cure.

Now, aiming to break a bottleneck between the test tube and the drug store, doctor's office and patient's bedside, the United States government is moving to speed the delivery of new drugs and therapies. Its latest tool: a reorganization inside the National Institutes of Health (NIH), the nation's premier agency for biomedical and behavioral research.

Dr. Francis S. Collins, the geneticist who leads the NIH, is steering a proposal to carve out a new center devoted to translating scientific discoveries into medical gains at a pace not seen before. It's an ambitious assault on the "valley of death," the chasm into which so many experimental treatments fall.

Far more than just a few additional offices in a sprawling network, the institute, provisionally named the National Center for Advancing Translational Sciences, would absorb some of the government's top medical research and financing efforts: a nearly half-billiondollar showcase grant program, the newly established Cures Acceleration Network and more.

If bureaucratic hurdles are part of the problem in bringing drugs, devices, diagnostics and therapies to patients, as most believe, can another new bureaucracy really be the answer? There is skepticism about that.

But Dr. Arthur H. Rubenstein, who led hearings for an NIH advisory group charged with studying the issue, says stakeholders seem largely to agree that so-called translational medicine is an ethos, a process - and now an institute - whose time has come.

"We really consulted very, very widely," says Rubenstein, dean of the University of Pennsylvania School of Medicine in Philadelphia. "The feeling,

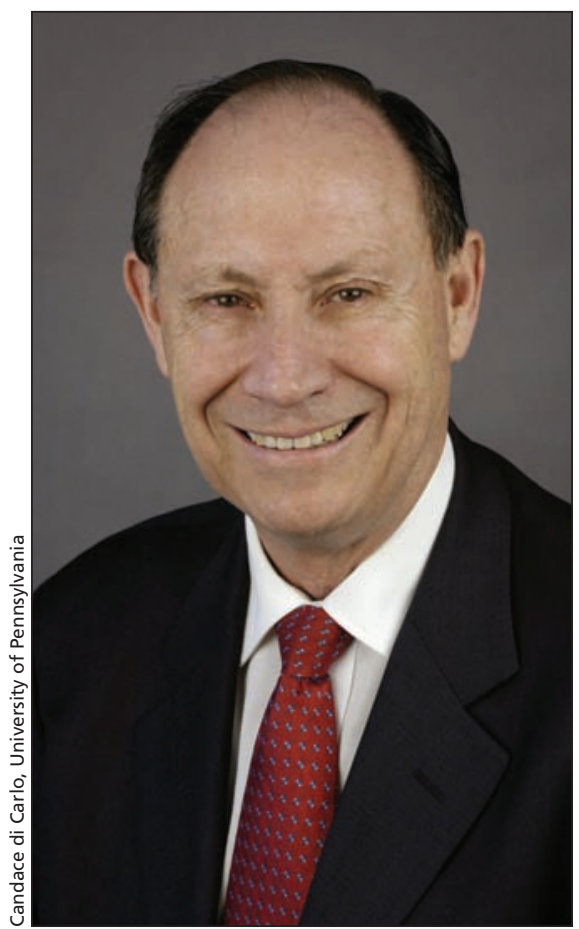

"In the last 10 years or a little longer there's been a huge investment in basic science both by the government and the private sector. And the disappointment has been the output - the number of new drugs," says Dr. Arthur H. Rubenstein, dean of the University of Pennsylvania School of Medicine in Philadelphia.

from many of these people, was that the current model is broken and we needed a new approach."

"In the last 10 years or a little longer there's been a huge investment in basic science both by the government and the private sector. And the disappointment has been the output — the number of new drugs."

He calls that output "meager."

The NIH is a mammoth enterprise. It plows more than US\$30 billion a year into medical research through grants to more than 325000 researchers and the work of its own 6000 scientists. With so much at stake, any substantial change in the agency's structure and money streams puts researchers inside and outside the agency on pins and needles.
Even so, the institution's Scientific Management Review Board, a panel of NIH officials and outside scientists, voted 12-1 in December 2010 to establish the center, endorsing the findings of Rubenstein's group (http ://smrb.od.nih.gov/dec/TMAT_Meeting _Formatted.pdf).

As planned, the center will administer the Cures Acceleration Network, a still-unfunded creation of President Barack Obama's health reform law that is aimed at supporting rapid deployment of high-need cures. The center will also house the agency's molecular libraries screening program, the government's initiative for rare and neglected diseases and its Clinical and Translational Science Awards, a grant program worth some US\$490 million a year.

"The idea was really to coordinate, streamline and bring the best brains together," Rubenstein says, tapping agencies "that have been trying to do the same thing, but not very successfully."

The proposal is in the hands of Health and Human Services Secretary Kathleen Sebelius, who will pass it on to Congress while the administration's accountants examine implications for the budget. Collins hopes to have the new center running by the fall.

Federal law limits the NIH to 27 institutes, which it already has. Collins is steering a parallel proposal to combine the agency's alcohol and drug abuse institutes, which would free up a slot. If that doesn't happen in time, Congress would need to approve a temporary workaround.

John Burklow, Collins' spokesman, says he sees no particular red flags in the road ahead. But he cautions that there is no clear precedent for bringing this center into being because it is being driven by scientists instead of the usual sponsors, legislators.

About $95 \%$ of researched drugs ultimately prove to be ineffective or unsafe, and failure often comes late in 
the game after millions have been spent and a succession of preclinical tests and clinical trials has unfolded. Successful drugs take an average of eight years to reach the market.

No wonder buzzwords such as "quick-win" and "fast-fail" are taking hold among proponents of translational research.

"It is time for a new view and not an incremental tweak," Collins told his staff in December 2010. "It is clear that scientific advances, many supported by $\mathrm{NIH}$, are providing new insights into the molecular causes of disease at a dizzying rate. And many of these insights are potentially actionable, suggesting new approaches to prevention or treatment that need to be tested."

Yet the "long timelines between such ideas and their reaching the market are frustrating and sometimes they never get there at all," he added (http ://feedback.nih.gov/index.php/category /ncats/ncats-updates/).

The hurry-up impulse at work in the NIH is spreading in academia, too.

In May 2010, Andy Grove, former CEO and chairman of Intel Corp., pledged US\$1.5 million to start a master's program in translational medicine at the University of California.

Dealing with his own prostate cancer and now Parkinson's disease over more than a decade, the entrepreneur became an impatient patient, frustrated that science could heal lab mice but fail people. He set out to instill the engineering and marketing drive of Silicon Valley in medical research.

"What we have learned from decades of rapid development of information technology is that the key is relentless focus on 'better, faster, cheaper' - in everything," Grove said in bestowing the gift.

But the notion that biology can be ramped up like a semiconductor-chip production line has not always flown with everyone.

Pharmaceutical chemist Derek Lowe, who has worked on drug discoveries for schizophrenia, Alzheimer disease, diabetes, osteoporosis and more, wrote that the problem is not a lack of urgency (http ://pipeline.corante.com/archives/2007 /11/06/andy_grove_rich_famous_smart _and_wrong.php). “And we don't suffer from a lack of hard-charging modern management techniques, that's for sure," he added. "What we suffer from is working on some of the hardest scientific problems in the history of the species." - Cal Woodward, Washington, DC

CMAJ 2011. DOI:10.1503/cmaj.109-3777 